\title{
Measurement of Pregnancy-Associated Plasma Proteins during Human Gestation
}

\author{
Tsue-Ming Lin, Seymour P. Halbert, and William N. Spellacy \\ From the Departments of Pediatrics and of Obstetrics and Gynecology, \\ University of Miami School of Medicine, Miami, Florida 33152
}

\begin{abstract}
A в S T RA C T Studies of four pregnancy-associated plasma proteins (PAPP's) were made on 206 plasma samples obtained from 175 pregnant women between 12 and $44 \mathrm{wk}$ of gestation. The concentration of three PAPP's (A, C, and D) were assayed by quantitative crossed immunoelectrophoresis. They showed a gradual but small rate of increase during the 2nd trimester, which became more rapid in the 3rd trimester. PAPP-A continued to rise steadily during this period, while PAPP-C and PAPP-D (recently identified as human placental lactogen) tended to reach a plateau. Although PAPP-B could not be quantitated because of technical problems, it was detected in over $50 \%$ of the samples from the last 2 mo of gestation, but was almost never seen in those obtained during the 12th-28th wk of gestation. Various parameters were analyzed to determine their possible correlation with the PAPP levels during the last month of gestation. The race and age of the mother showed no influence on any of the PAPP's, while parity, sex of fetus, and infant birth weights appeared to affect the plasma concentration of some of the PAPP's. In the two instances studied, mothers of twins showed abnormally high PAPP levels.
\end{abstract}

\section{INTRODUCTION}

Previous studies from our laboratory have revealed the existence of up to four pregnancy-associated plasma proteins (PAPP's) ${ }^{1}$ in women during the 2 nd and $3 \mathrm{rd}$ trimesters of normal gestation $(1,2)$. These proteins differed from each other immunologically and in their physicochemical properties. Three of them were partially purified and were used in the production of mono-

Received for publication 22 January 1974 and in revised form 24 April 1974.

${ }_{1}$ Abbreviations used in this paper: HCG, human chorionic gonadotropin; HPL, human placental lactogen; PAPP, pregnancy-associated protein; RIA, radioimmunoassay; $\mathrm{SP}_{1,2,3}$, pregnancy-associated proteins described by Bohn (18). specific antisera (3). Analogous PAPP's were also found in the rat and mouse, although there was little or no immunological relationship between these proteins of the three species (4). Other investigators have also described various pregnancy-associated proteins in man by employing several assay methods and/or reagents (5-21).

One of the PAPP's (PAPP-D) has recently been identified immunologically as human placental lactogen $(3,22)$, while another (PAPP-C) was shown to be identical to the pregnancy-specific $\beta_{1}$-glycoprotein $\left(\mathrm{SP}_{1}\right)$ described by Bohn $(3,18)$. PAPP-A may represent a heretofore undescribed PAPP, based on published data and on observations obtained in our laboratory showing that it was unrelated immunologically to Bohn's pregnancy-associated proteins, $\mathrm{SP}_{2}$ and $\mathrm{SP}_{3}$, and to Berne's $\alpha_{2}$-pregnoglobulin $(18,20,23)$. PAPP-B also appears to be unrelated to Bohn's $\mathrm{SP}_{2}$ and $\mathrm{SP}_{3}$ proteins (18). Based on reports in the literature $(18,21,23,24)$ and unpublished observations in our laboratory, there is reason to believe that the well-known "pregnancy zone" protein is identical to the protein which has been variously designated $\mathrm{SP}_{3} \mathrm{Xh}, \mathrm{Xm}, \alpha_{2}$-pregnoglobulin, new serum $\alpha$-macroglobulin, and the pregnancy-associated globulin (PAG or Pal) (5, 7, 10-12, 18-21, 23).

In the present study, the relative concentrations of three of the PAPP's (A, C, and D) were determined in plasma from pregnant women during the 2nd and $3 \mathrm{rd}$ trimesters. These data may be helpful in designing further definitive experimental studies aimed at better understanding the biological functions and clinical significance of these pregnancy-associated proteins.

\section{METHODS}

Pregnancy plasma. 206 samples of pregnancy plasma were obtained from 175 women between 12 and $44 \mathrm{wk}$ of gestation. In 24 cases, 2 samples were from single individuals at different times, while in 4 instances, 3 samples were taken serially. The specimens were stored at $-20^{\circ} \mathrm{C}$ until assayed. A review of the medical records showed that approximately one half of the women had associated pregnancy complications such as hypertension or diabetes mel- 
litus. Approximately $60 \%$ of the patients were negro, the remainder being caucasian. Their ages ranged from 14 to $41 \mathrm{yr}$. There were two women who delivered twins.

Antibody. A single lot of immunoglobulin concentrate from appropriately absorbed hyperimmune rabbit antisera to human pregnancy plasma was prepared as previously described $(1,2)$. It was stored at $-20^{\circ} \mathrm{C}$ in aliquots of 2 $\mathrm{ml}$, which was sufficient for one set of assays. This antibody concentrate failed to show any visible reactions with individual plasmas from 26 nonpregnant normal women and 24 normal men.

Assay. The antibody crossed immunoelectrophoresis method was employed to determine the pregnancy protein concentrations $(25,26)$. Warm molten $1 \%$ agarose in veronal acetate buffer (ionic strength $=0.025, \mathrm{pH} 8.6$ ) was introduced by capillarity into a 0.18 -cm-thick space between two $5 \times 5-\mathrm{cm}$ glass plates. The top plate was carefully removed after the gel had solidified. Three parallel equidistant $3-\mathrm{mm}$ wells and a linear cut $2 \mathrm{~mm}$ above the well edges were made simultaneously with a machined device. Samples of plasma $\left(\begin{array}{lll}10 & \mu l\end{array}\right)$ were introduced into the wells while the current was on, after the agarose plates had been equilibrated for $10 \mathrm{~min}$ at $2 \mathrm{~V} / \mathrm{cm}$ in an electrophoresis cell with reservoirs containing the same veronal acetate buffer. Electrophoresis was carried out for exactly $1 \mathrm{~h}$ for each plate under these conditions. At this time, the plate was carefully removed and processed for the second electrophoresis. A second linear cut was made $20 \mathrm{~mm}$ above the wells, and the agarose gel between this and the earlier cut was removed. A clean $5 \times 5-\mathrm{cm}$ glass slide was placed on top of the remaining segments of gel. Warm $\left(50^{\circ} \mathrm{C}\right) 1 \%$ agarose solution containing the antibody concentrate at a final dilution of 1:10 was introduced between the two glasses as described earlier. After gelling, the top glass was removed with great care. The plates were then subjected to the second electrophoresis overnight $(2 \mathrm{~V} / \mathrm{cm})$ perpendicular to the first run, with the gel side down and with the anode on the antibody side. Random wells in different plates were charged with four twofold serial dilutions of a reference standard plasma. The latter was a pool of 3rd-trimester pregnancy plasmas that has been concentrated fourfold by lyophilization. After electrophoresis in the second direction, the plates were further developed for 2 days at room temperature. The unstained patterns were photographed with the Cordis Immunodiffusion Camera (Cordis Laboratories, Miami, Fla.) at $\times 1.8$ magnification. Measurements of the precipitin "hills" of the PAPP-A and PAPP-C systems could readily be made from these photographs, but the other two reactions were usually too faint for clear direct visualization. For these (PAPP-B and PAPP-D), the slides were dialyzed and dried after being covered with wet Whatman \#1 filter paper to avoid distortion or shrinkage. After removing any lint, the precipitin hills were stained with amido black for measurement. Under these assay conditions, the migration of the PAPP's in the first direction was rather limited, and the precipitin hills approached those seen in the "rocket" technic of Laurell (37).

Analysis of the patterns obtained with serial dilutions of the reference pregnancy plasma revealed that measurement of the heights of the hills yielded relative quantitative values equivalent to those obtained by planimetry of the areas subtended by them. Both parameters have been used for such quantitation (36), and in the present study, the height of each system was employed. This value was measured from a line through the centers of the wells to the tips of the hills. The values obtained for each dilution of the reference standard plasma concentrate were plotted on an arithmetric scale, which yielded a straight line in the dilutions tested $(1: 2,1: 4,1: 8,1: 16)$. An arbitrary concentration of $100 \mathrm{U} / \mathrm{ml}$ for each PAPP was assigned to the concentrated reference standard plasma, and the unknown values relative to this reference were read from the standard curves. The latter were run in each experiment. Unit values less than 6 or greater than 50 were roughly estimated by extrapolation of the standard curves.

The four pregnancy protein immune systems in the crossed antibody immunoelectrophoresis had been identified earlier in tests with the purified PAPP's $(2,3)$. In the present study, the precipitin hills were readily identified on the basis of their electrophoretic mobilities, their times of appearance, and the characteristics of the precipitin lines. PAPP-A migrated most rapidly, followed closely by PAPP-D. However, the latter developed more slowly than the PAPP-A system, was much fainter, and usually required staining to be visualized. PAPP-C showed a rapidly developing intense and thick line, which migrated well behind PAPP-A and PAPP-D. Although PAPP-B migrated with PAPP-C, the PAPP-B system was delayed in appearance and was very weak in intensity, almost always requiring staining to be seen. For these reasons, the latter was often masked by the PAPP-C reaction and was only clearly seen when its hill was higher than the PAPP-C system. Because of this, PAPP-B could not be analyzed quantitatively in the present study.

All samples were tested in duplicate on different occasions. A typical plate and standard curves are shown in Fig. 1. The accuracy of the method was equivalent to that reported by Clarke and Freeman (26). In some cases, when the concentration of one of the PAPP's was so high that a complete hill was not produced, the sample was retested by utilizing a higher antibody concentration. The plasma content of human placental lactogen (HPL) was also measured by using a solid phase radioimmunoassay (RIA) procedure (27).

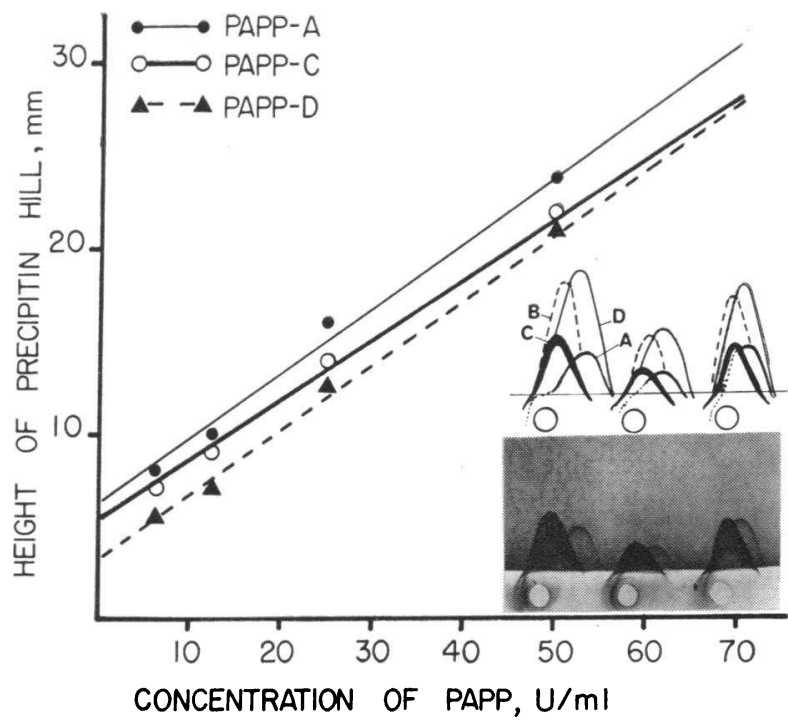

Figure 1 Standard curves of PAPP's from dilutions of reference pregnancy plasma for assay of unknowns. Insets show a typical stained crossed immunoelectrophoresis plate of three individual late pregnancy plasma samples. 


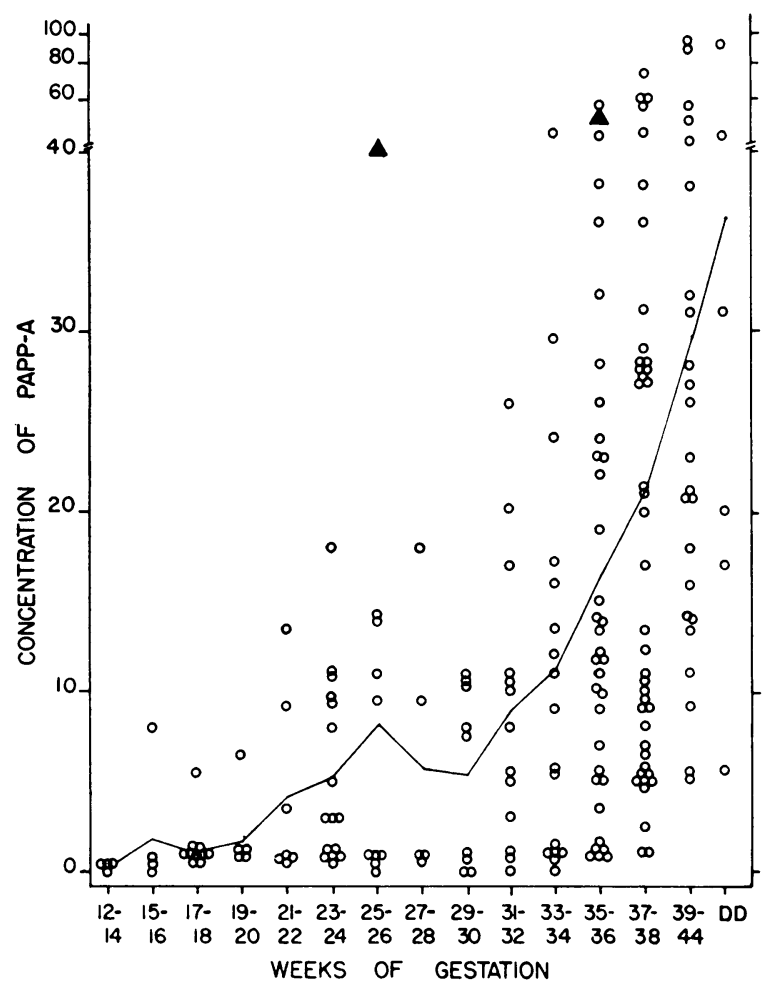

FIGURE 2 Scatter diagram showing the plasma concentration of PAPP-A in 206 specimens from women in the last 2 trimesters of gestation. The line connects group means; the triangles are results for the twin pregnancies. DD, day of delivery. The concentrations above 40 are plotted on a condensed scale.

Statistical analysis of these data employed the Student's $t$ test. Probability values were taken from a two-tailed table, and values of 0.05 or less were considered significant. The coefficient of correlation $(r)$ was calculated as described in Snedecor and Cochran (28). Nonparametric statistical methods were also used (rank sum and rank correlation coefficient) (28) for these analysis, with similar results.

\section{RESULTS}

All 206 samples showed measurable levels of PAPP-C, while PAPP-A was detectable in all but 5 of the specimens obtained after the 17 th wk. Two earlier specimens also failed to show PAPP-A. The five later samples lacking detectable PAPP-A were derived from two women, and the absence of PAPP-A was also noted in immunodiffusion. PAPP-D was detectable in 158 of the 206 specimens, and most of those not showing this protein were collected during the 2nd trimester of pregnancy.

The individual concentrations of PAPP-A, C, and D during gestation and the mean curves for each are shown in Figs. 2, 3, and 4, respectively. The spread of the values was considerable, but it is clear that PAPP-A rose steadily during mid-pregnancy and at a steeply increas- ing rate from the 29th wk until labor. In the cases of PAPP-C and PAPP-D, both appeared to reach plateau values during the late period of gestation.

In the six samples obtained on the day of delivery, PAPP-D levels had dropped precipitously, and this protein was not detectable in five of the six specimens. This was not the case for PAPP-A, B, and C.

As indicated above, the PAPP-B system often could not be seen regularly unless its hill was higher than the intense PAPP-C hill. Bearing this limitation in mind, the patterns were examined for the presence of PAPP-B, and results are summarized in Table I. It may be noted that PAPP-B was almost never seen under these assay conditions before the 28th wk of gestation. It became detectable in approximately one fourth of the specimens obtained during the 8th mo and was found in one half of the samples at or after $33 \mathrm{wk}$ of gestation.

Attempts were made to determine whether high levels of one PAPP was usually accompanied by high levels of the others during the last month of pregnancy. Analysis of these data revealed very little correlation between the concentrations of the PAPP's in individual samples. $r$

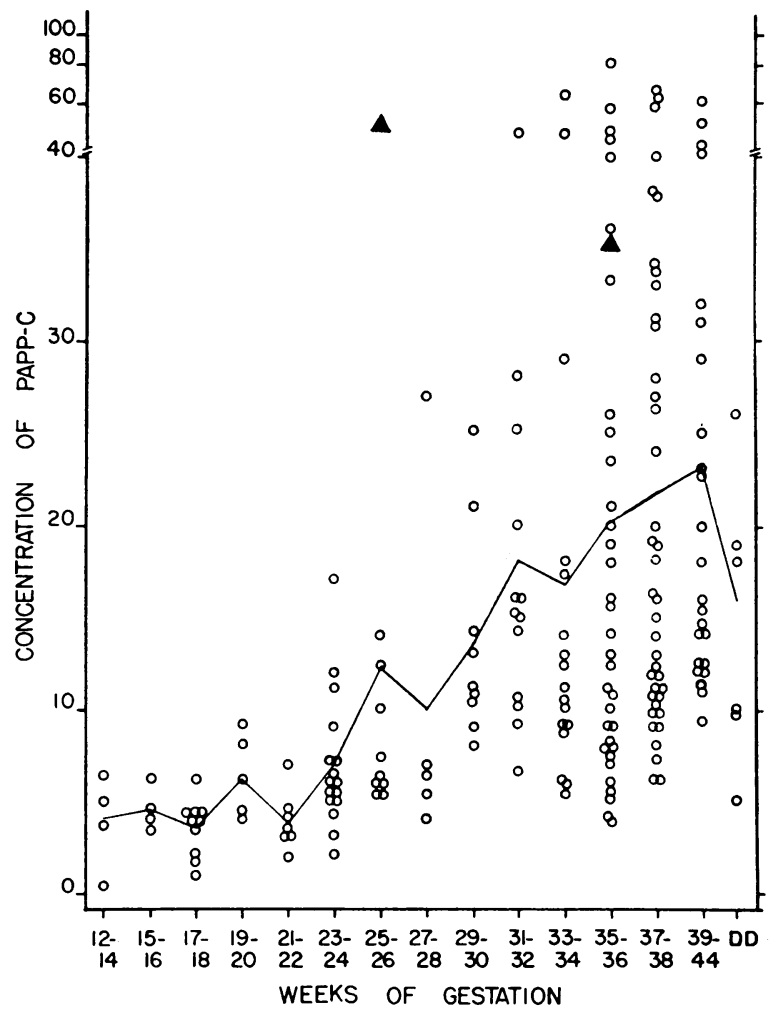

Figure 3 Scatter diagram showing the plasma concentration of PAPP-C in 206 specimens from women in the last 2 trimesters of gestation. The line connects group means; the triangles are results for the twin pregnancies. $\mathrm{DD}$, day of delivery. The concentrations above 40 are plotted on a condensed scale. 


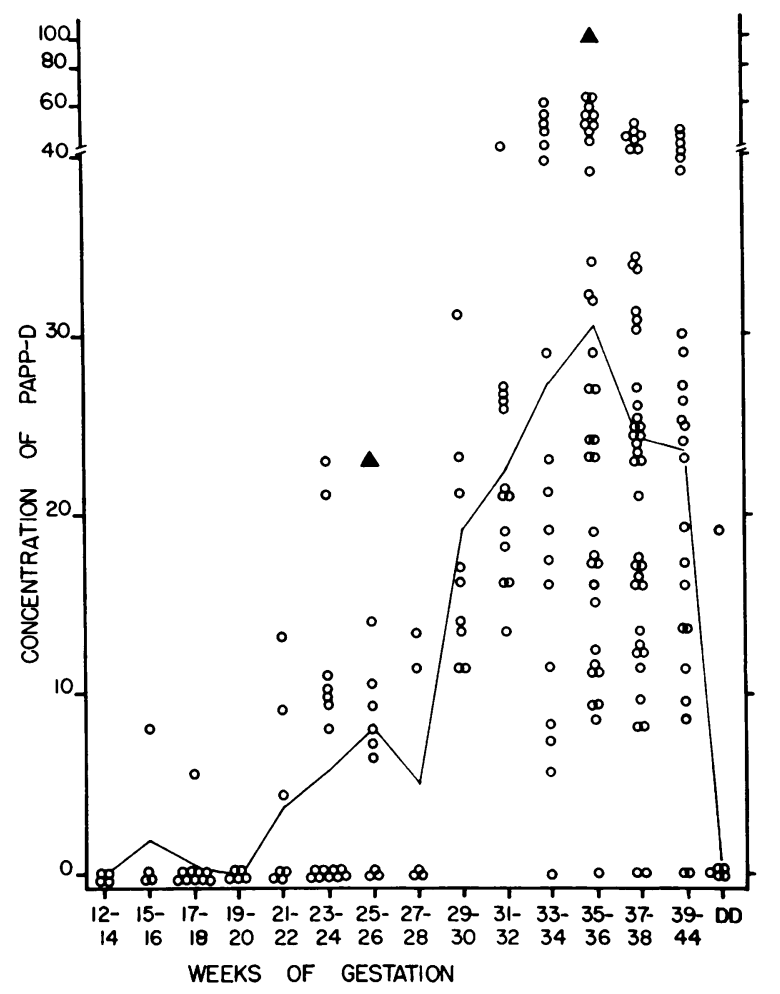

Figure 4 Scatter diagram showing the plasma concentration of PAPP-D in 206 specimens from women in the last 2 trimesters of gestation. The line connects group means; the triangles are results for the twin pregnancies. DD, day of delivery. The concentrations above 40 are plotted on a condensed scale.

ranged from -0.011 to 0.298 in various paired comparisons. Thus, as an example, a given specimen might have a quite high PAPP-A but low $\mathrm{C}$ and $\mathrm{D}$ concentrations.

During the last month of gestation, both PAPP-A and PAPP-C in pregnancies with male fetuses were significantly higher than those with female fetuses; no such difference was observed for PAPP-D (Table II). It

TABLE I

Detection of PAPP-B in Samples of Pregnancy Plasma by Crossed Immunoelectrophoresis at Different Stages of Gestation

\begin{tabular}{ccccc}
\hline $\begin{array}{c}\text { Wk of } \\
\text { gestation }\end{array}$ & $\begin{array}{c}\text { No. } \\
\text { examined }\end{array}$ & \multicolumn{2}{c}{$\begin{array}{c}\text { PAPP-B } \\
\text { detected }\end{array}$} \\
\hline $12-28$ & 61 & No. & $\%$ \\
$29-32$ & 22 & 5 & 23 \\
$>33$ & 117 & 60 & 51 \\
Day of delivery & 6 & 5 & 83
\end{tabular}

* This specimen was obtained from a woman who gave birth to twins.
TABLE II

Effect of Fetal Sex on PAPP's $(A, C$, and D) in Maternal Blood Obtained during the Last Month of Gestation

\begin{tabular}{ccccc}
\hline & \multicolumn{2}{c}{$\begin{array}{c}\text { Concentration } \\
\text { of PAPP's with }\end{array}$} & & \\
\cline { 2 - 4 } & $\begin{array}{c}\text { Male } \\
\text { fetus } \\
(n=35)\end{array}$ & $\begin{array}{c}\text { Female } \\
\text { fetus } \\
(n=26)\end{array}$ & $t$ & $P$ \\
\hline PAPP'S & $30.0 \pm 4.4$ & $19.6 \pm 3.3$ & 2.019 & $<0.05$ \\
A & $26.1 \pm 3.2$ & $18.2 \pm 2.4$ & 2.117 & $<0.05$ \\
D & $25.0 \pm 2.4$ & $22.3 \pm 2.9$ & 0.783 & NS \\
\hline
\end{tabular}

was also noted that fetal size influenced PAPP-C concentration. Higher levels of this protein occurred during the last month of gestation in those pregnancies where the infant birth weight was elevated (Fig. 5). Infant birth weight did not appear to affect the concentrations of PAPP-A or PAPP-D, however. Maternal age, as well as race, bore no relation to the plasma concentrations of any of the PAPP's. There was a tendency for women that had three or more full term or premature pregnancies to reveal low levels of PAPP-A and PAPP-D during the last month of gestation (Table III). Attempts were made to analyze matched groups with regard to parity, fetal sex, and newborn weight. The same trends seen above were observed in most cases, but the smaller sample sizes sometimes did not show statistical significance. Analysis of the data based on unit weight of the infant (kilograms) also showed the same trends. It

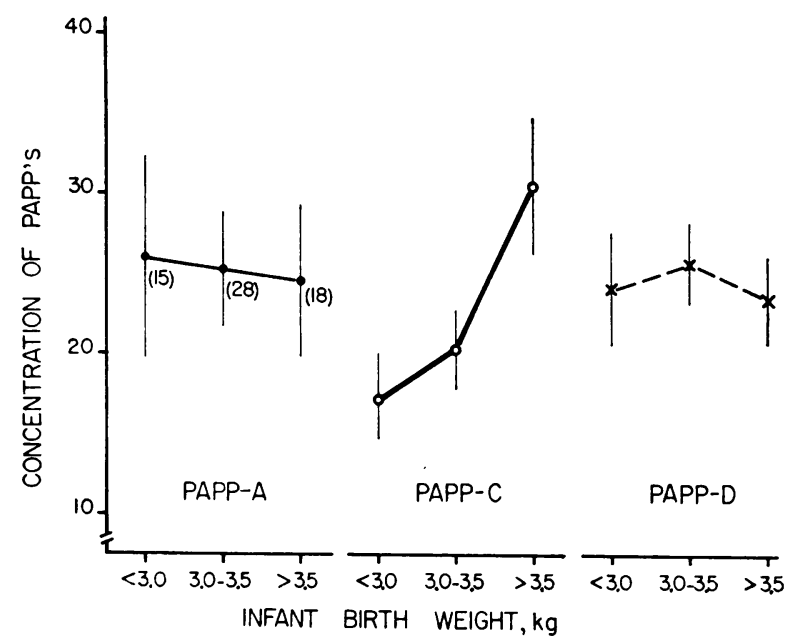

Figure 5 Relationship between the newborn weight and the maternal plasma concentration of PAPP's during the last month of gestation. Mean, SE, and sample number (in parenthesis) are given. The PAPP-C level in pregnancy with newborn weight heavier than $3.5 \mathrm{~kg}$ was significantly greater than those in the other two groups. 
TABLE III

Effect of Parity on the Maternal Plasma Concentration of PAPP-A and PAPP-D during the Last Month of Gestation

\begin{tabular}{|c|c|c|c|c|}
\hline \multirow[b]{2}{*}{ Protein } & \multicolumn{3}{|c|}{ Mean $\pm \mathrm{SE}$ values in women with } & \multirow[b]{2}{*}{$\begin{array}{l}\text { Statistical } \\
\text { analysis } \\
(a \text { vs. } c)\end{array}$} \\
\hline & $\begin{array}{l}\text { No previous } \\
\text { preg- } \\
\text { nancy* }(a) \\
(n=22)\end{array}$ & $\begin{array}{l}\text { One or two } \\
\text { previous } \\
\text { pregnan- } \\
\text { cies* }(b)_{(n=22)}\end{array}$ & 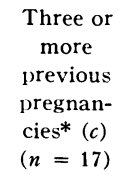 & \\
\hline PAPP-A & $28.4 \pm 4.2$ & $28.2 \pm 5.4$ & $18.0 \pm 2.5$ & $\begin{aligned} t & =1.966 \\
0.05 & <P<0.10\end{aligned}$ \\
\hline PAPP-D & $28.0 \pm 2.6$ & $24.2 \pm 3.0$ & $19.8 \pm 2.2$ & $\begin{array}{l}t=2.291 \\
P<0.05\end{array}$ \\
\hline
\end{tabular}

* Full term and premature pregnancies.

is apparent that more extensive data are required to establish these correlations.

Since PAPP-D was recently identified as HPL, the values of this hormone as determined by RIA and crossed immunoelectrophoresis were compared statistically. The results from 40 specimens showed $r=0.846(P<0.01)$, which supports the relative accuracy of the crossed immunoelectrophoretic method used.

\section{DISCUSSION}

Previous studies from this laboratory have shown that three PAPP's which could be readily visualized by simple gel diffusion methods (PAPP-A, C, and D) were distinct from each other immunologically, as well as physicochemically (1-3). The present report implies that their biological functions might also be different, since the plasma concentrations of each showed little correlation with the others, and they varied appreciably with respect to their rates of change during the 2 nd and 3rd trimesters of pregnancy. The fourth PAPP detected with our antisera (PAPP-B) could not be quantitated regularly because of overlap with the PAPP-C systems.

PAPP-A levels rose steadily throughout gestation, at an increasing rate during the last part of pregnancy. On the other hand, PAPP-C and PAPP-D appeared to reach a plateau level during this latter period. Since PAPP-D was recently identified as HPL (3), it is worth noting that the pattern observed here agrees with published data concerning the levels of this hormone during pregnancy, as determined by RIA methods (27). It was also recently found that PAPP-C is immunologically identical to Bohn's pregnancy-specific $\beta_{1}$-glycoprotein, $\mathrm{SP}_{1}$ (18). The increase in concentration of PAPP-C during pregnancy noted above agrees with limited serial observations made by Bohn in eight normal pregnant women, using radial immunodiffusion with specific anti-SP1 antiserum.
Although PAPP-B could not be readily measured because of the technical reasons mentioned, it was not detected before the $28 \mathrm{th}$ wk of gestation, except in one mother with twins. It could very well have been present at low concentrations during this early period, becoming increasingly evident towards the end of pregnancy. These findings support the earlier conclusions based on immunological findings $(1,3)$ that PAPP-B, as well as the other PAPP's, are unrelated to human chorionic gonadotropin (HCG), since this hormone is known to peak early in pregnancy, subsequently decreasing in concentration. It is unlikely that any of the PAPP's represent human chorionic thyrotropin, because the plasma levels of this hormone also peak early in pregnancy (29). Quantitation of PAPP-B will be readily feasible when monospecific antibody to this protein is developed.

Although the sample size in the present study was relatively small, analysis of several parameters, such as weight of the newborn, sex of fetus, maternal age, parity, and race, have suggested that some of these factors might be correlated with concentrations of these proteins. It is interesting to note that both PAPP-A and PAPP-C appeared to be slightly elevated in mothers carrying male fetuses, as compared to female fetuses. This was not true for PAPP-D, which confirms findings made by RIA (30). Although the reasons for such a correlation with fetal sex are not clear, it is worth mentioning that the maternal levels of certain hormones, such as HCG and progesterone, have also been found to be correlated with the sex of the infant (3133). It was also noted that the infant birth weight appears to be correlated with the level of PAPP-C and that increasing parity resulted in lower PAPP-A and PAPP-D levels. Because these preliminary observations included data obtained with samples from women with several complications of pregnancy, further stud- 
ies are needed to confirm such correlations in normal pregnancies. Such studies are underway.

Although the function of the PAPP's are not known at present, recent studies by Bohn suggest that the pregnancy-specific PAPP-C ( $\left.\mathrm{SP}_{1}\right)$ may weakly bind three steroid hormones (estriol, estradiol, and testosterone) (34). In comparison, he found that his pregnancy-associated glycoproteins, $\mathrm{SP}_{2}$ and $\mathrm{SP}_{3}$, bound these steroids with greater affinity, $\mathrm{SP}_{2}$ showing preferential association for testosterone and estradiol, while $\mathrm{SP}_{3}$ had the greatest affinity for estriol. It should be emphasized that both $\mathrm{SP}_{2}$ and $\mathrm{SP}_{3}$ ( $\alpha$-pregnoglobulin, PAG, etc.) are not specific for pregnancy but are readily detectable in an appreciable proportion of normal individuals and in a large percentage of patients with cancer or in those taking hormonal contraceptives. In fact, Bohn has recently preferred to designate them as acute phase proteins (35). In contrast, all of the PAPP's described here appear to be generally pregnancy specific, since none of them have been detected by the methods used in nonpregnant normal male or female plasma, in plasma from patients with a variety of cancers not derived from the trophoblast, or in women receiving hormonal contraceptives (3).

\section{ACKNOWLEDGMENTS}

This study was supported by a research grant from the National Institutes of Health (no. HD5736).

\section{REFERENCES}

1. Gall, S. A., and S. P. Halbert. 1972. Antigenic constituents in pregnancy plasma which are undetectable in normal nonpregnant female or male plasma. Int. Arch. Allergy Appl. Immunol. 42: 503-515.

2. Lin, T. M., S. P. Halbert, D. Kiefer, W. N. Spellacy, and S. Gall. 1974. Characterization of four human pregnancy-associated plasma proteins. Am. J. Obstet. Gynecol. 118 : 223-236.

3. Lin, T. M., S. P. Halbert, D. Kiefer, and W. N. Spellacy. 1973. Three pregnancy-associated human plasma proteins: purification, mono-specific antiserum and immunological identification. Int. Arch. Allergy Appl. Immunol. $47: 35-53$.

4. Lin, T. M., S. P. Halbert, and D. Kiefer. 1974. Pregnancy-associated serum antigens in the rat and mouse. Proc. Soc. Exp. Biol. Med. 145: 62-66.

5. Thornes, R. D. 1958. Proteins of pregnancy. M.D. Thesis, Dublin University. $64 \mathrm{pp}$.

6. MacLaren, J. A., R. D. Thornes, C. C. Roby, and D. E. Reid. 1959. An immunologic characteristic of the serum of normal pregnancy. Am. J. Obstet. Gynecol. 78: 939946.

7. MacLaren, J. A., D. E. Reid, A. A. Konugres, and F. H. Allen, Jr. 1966. Pal, a new inherited alpha-2-globulin of human serum. Vox Sang. 11: 553-560.

8. Smithies, O. 1959. Zone electrophoresis in starch gels and its application to studies of serum proteins. Adv. Protein Chem. 14: 65-113.

9. Hirschfeld, J., and U. Soderberg. 1960. Immuno-electrophoretic demonstration of precipitating components in sera from pregnant women. Nature (Lond.). 187: 332333.

10. Afonso, J. F., and R. R. De Alvarez. 1963. Further starch gel fractionation of new protein zones in pregnancy. Am. J. Obstet. Gynecol. 86: 815-819.

11. Bundschuh, G. 1966. "Xh"ein genetisch determiniertes $\alpha_{2}$-Globulin. Acta Biol. Med. Ger. 117: 349-356.

12. Kueppers, F. 1969. Studies on the $\mathrm{Xh}$ antigen in human serum. Humagenetik. 7 : 98-103.

13. Robinson, J. C., W. T. London, and J. E. Pierce. 1966. Observations on the origin of pregnancy-associated plasma proteins. Am. J. Obstet. Gynecol. 96: 226-230.

14. Margolis, J., and K. G. Kenrick. 1969. "Pregnancyprotein" in polyacrylamide gradient-gel electrophoresis. Aust. J. Exp. Biol. Med. Sci. 47: 637-641.

15. Hofmann, R., H. Friemel, and E. Behm. 1969. Immunchemische Untersuchungen zum Problem der "pregnancy zone". I. Anti-Schwangeren-Immunserum. Arch. Gynackol. 208: 178-186.

16. Studd, J. W., J. D. Blainey, and D. E. Bailey. 1970. A study of serum protein changes in late pregnancy and identification of the pregnancy zone protein using antigen antibody crossed immunoelectrophoresis. J. Obstet. Gynaecol. Br. Commonw. 77 : 42-51.

17. Beckman, L., T. Stigbrand, and B. von Schoutz. 1971 Induction of the "pregnancy zone" protein by oral contraceptives. Acta Obstet. Gynecol. Scand. 50: 369-371.

18. Bohn, H. 1971. Nachweis und Charakterisierung von Schwangerschafts-proteinen in der menschlichen Placenta, sowie ihre quantitative immunologische Bestimmung im Serum Schwangerer Frauen. Arch. Gynaekol. 210: $440-457$.

19. Stimson, W. H., and L. Eubank-Scott. 1972. The isolation and partial characterization of a new $\alpha$-macroglobulin from human pregnancy serum. FEBS (Fed. Eur. Biochem. Soc.) Lett. 23: 298-308.

20. Berne, B. H. 1973. Alpha-2 pregnoglobulin (pregnancyzone protein) a unique macroglobulin elevated in pregnancy, contraception and cancer. Fed. Proc. 32: 677. (Abstr.)

21. Dunston, G. M., and H. Gershowitz. 1973. Further studies of $\mathrm{Xh}$, a serum protein antigen in man. Vox Sang. $24: 343-353$.

22. Saxena, B. N. 1971. Protein-polypeptide hormones of the human placenta. Vitam Horm. 29: 95-151.

23. Berne, B. H. 1973. Alpha-2 pregnoglobulin-A pregnancy-associated macroglobulin elevated by estrogen and oral contraceptive administration. Internat. Res. Commun. System. (73-10) 10-26-4.

24. Hofmann, R., W. Straube, B. Klausch, H. Friemel, and J. Gunther. 1972. Immunchemische Untersuchungen zum Problem der "pregnancy zone". VI. Vorkommen, Identifizierung und Nachweis des schwangerschaftstypischen Proteins der Schwangerschaftszone. Arch. Gynaekol. 212 : 246-257.

25. Laurell, C. B. 1965. Antigen-antibody crossed electrophoresis. Anal. Biochem. 10: 358-361.

26. Clarke, H. G. N., and T. Freeman. 1966. A quantitative immuno-electrophoresis method (Laurell electrophoresis). Protides Biol. Fluids Proc. Colloq. Bruges. 14: 503-509.

27. Spellacy, W. N., E. S. Teoh. W. Buhi, S. A. Birk, and S. A. McCreary. 1971. Value of human chorionic somatomammotrophin in managing high risk pregnancies. Am. J. Obstet. Gynecol. 109: 588-598.

28. Snedecor, G. W., and W. G. Cochran. 1967. Statistical 
Methods. Iowa State University Press, Inc., Ames, Iowa. 6th edition. 593 pp.

29. Hennen, G., J. G. Pierce, and P. Freychet. 1969. Human chorionic thyrotropin: further characterization and study of its secretion during pregnancy. J. Clin. Endocrinol. Metab. 29: 581-594.

30. Spellacy, W. N., W. C. Buhi, J. D. Schram, S. A. Birk, and S. A. McCreary. Control of human chorionic somatomammotrophin levels during pregnancy. Obstet. Gynecol. 37: 567-573.

31. Brody, S., and G. Carlström. 1965. Human chorionic gonadotropin pattern in serum and its relation to the sex of the fetus. J. Clin. Endocrinol. Metab. 25: 792797.

32. Crosignani, P. G., T. Nencioni, and B. Brambati. 1972. Concentration of chorionic gonadotrophin and chorionic somatomammotrophin in maternal serum, amniotic fluid and cord blood serum at term. J. Obstet. Gynecol. Br. Commonw. 79: 122-126.
33. Rawlings, W. J., and V. I. Krieger. 1964. Pregnanediol excretion and sex of the fetus. Fertil. Steril. 15: 173179.

34. Bohn, H., and T. Kranz. 1973. Untersuchungen uber die Bindung von steroidhormonen an menschliche Schwangerschaftsproteine. I. Identifizierung des schwangerschafts-assoziierten $\beta_{1}$ Glykoproteins mit dem Steroid-bindenden $\beta$-Globulin. Arch. Gyneakol. 215: 63-71.

35. Bohn, H. 1972. Charakterisierung der Schwangerschaftsassoziierten Glykoproteine als akute Phase Proteine. Ihr Nachweis im serum von Patienten mit $\mathrm{Tu}$ moren und anderen Erkrankungen. Arch. Gynaekol. 213: 54-72.

36. Wright, G. L., Jr., L. Pollack, and D. B. Roberts. 1974. Rapid two-dimensional immunoelectrophoresis of human serum proteins. Clin. Chem. 20: 30-35.

37. Laurell, C. B. 1966. Quantitative estimation of proteins by electrophoresis in agarose containing antibodies. Anal. Biochem. 15: 45-52. 